\title{
Effect of the exocrine pancreatic secretions on iron absorption ${ }^{1}$
}

\author{
H. KAVIN, R. W. CHARLTON, P. JACOBS, R. GREEN, \\ J. D. TORRANCE, AND T. H. BOTHWELL ${ }^{2}$ \\ From the C.S.I.R. Iron and Red Cell Metabolism Group, Department of Medicine, \\ University of the Witwatersrand, South Africa
}

EDITORIAL COMMENT The influence of pancreatic extract on iron salts and their absorption has been investigated in vitro, in experimental animals, and in patients with pancreatic insufficiency. It is suggested that the binding of iron by pancreatic extract is non-specific adsorption and that pancreatic exocrine secretions play little or no part in the physiological control of iron absorption.

The role of the exocrine secretions of the pancreas in the absorption of iron has been the subject of extensive investigation. There is a considerable body of evidence indicating that deficiency of the pancreatic secretions leads to excessive absorption of iron, and consists of observations both in experimental animals and in human subjects. The animal evidence includes the increase in carcass iron observed after pancreatectomy (Taylor, Stiven, and Reid, 1931), after ligation of the pancreatic duct (Taylor, Stiven, and Reid, 1935; Gillman, Gillman, Mandelstam, and Gilbert, 1947; Kinney, Finch, Kaufman, Hegsted, and Partington, 1950), and after pancreatic necrosis induced by ethionine (Kinney, Kaufman, and Klavins, 1955; Brozović, Popović, Obradović, and Pendić, 1966), or by protein malnutrition (Kaufman, Klavins, and Kinney, 1958). Similar observations have been reported in patients with pancreatic disease. An increase in tissue iron has been noted at necropsy in some subjects with fibrocystic disease of the pancreas (Andersen, 1938) and chronic pancreatitis (Banwell, Hutt, Marsden, and Blackman 1964). Furthermore, iron absorption has been reported to be increased in a proportion of patients with fibrocystic disease of the pancreas (Tönz, Weiss, Strahm, and Rossi, 1965) and chronic pancreatitis (Davis, 1961; Davis and Badenoch, 1962; Ball, 1964; Deller, 1965). It has even been suggested that idiopathic haemochromatosis is the consequence

\footnotetext{
${ }^{1}$ This work was supported in part by a grant (AMO4912-06) from the National Institutes of Health, U.S.A., and in part by a grant from the Atomic Energy Board, South Africa.

${ }^{2}$ Reprint requests should be addressed to Dr. T. H. Bothwell, Department of Medicine, Medical School, Hospital Street, Johannesburg, South Africa.
}

of a primary deficiency in the pancreatic secretions (Biggs and Davis, 1963).

On theoretical grounds the enhanced absorption of iron in pancreatic insufficiency could be due to diminished secretion of bicarbonate in the pancreatic secretions. The $p \mathrm{H}$ in the lumen of the duodenum is determined by the degree to which the acid entering from the stomach is neutralized. The solubility of inorganic iron salts is much greater at low $p \mathrm{H}$ levels, and insoluble ferric hydroxide complexes form as the $p \mathrm{H}$ rises. This is almost certainly the reason why iron absorption occurs predominantly in the proximal duodenum, since the $p \mathrm{H}$ rises progressively in the distal regions. Support for this contention is provided by a number of experimental observations. For example, it has been shown that segments of rat terminal ileum absorb iron briskly if acid is added to the luminal contents (Jacobs, Bothwell, and Charlton, 1966). Similarly, patients with achlorhydria absorb ferric iron more efficiently if it is administered with hydrochloric acid (Jacobs, Bothwell, and Charlton, 1964). It is therefore not surprising that the intraduodenal infusion of bicarbonate has been found to reduce iron absorption in some patients with chronic pancreatitis (Ball, 1964).

Other evidence suggests that bicarbonate is not the only pancreatic factor affecting iron absorption. The administration of commercial pancreatic extract to some patients with chronic pancreatic disease has been found to correct the excessive iron absorption (Davis and Badenoch, 1962; Saunders, Bank, Airth, and Williams, 1963; Davis and Biggs, 1964; Smith, 1964; Strahm, 1965; Weiss, 1965; Deller, 1965). In addition, pancreatic extract has been 
noted to decrease the uptake of iron by isolated loops of rat jejunum (Davis and Biggs, 1965). It has been claimed that the active principle is a watersoluble, heat-labile and partially dialysable polypeptide or protein (Biggs and Davis, 1966).

Despite the many reports suggesting an association between pancreatic disease and excessive iron absorption, there is other evidence indicating that the relationship is by no means clearcut. First, the increase in tissue iron stores which has been noted in some patients dying of mucoviscidosis has been reported almost exclusively in infants of less than 18 months and not in older children (Andersen, 1938; Craig, Haddad, and Shwachman, 1957; Stein, Porta, Powers, Leather, Linton, and Patterson, 1963; Longnecker, 1965). Furthermore, Smith, Rosello, Say, and Yeya (1955) and Longnecker (1965) reported iron deposits of similar degree in the tissues of infants dying of other diseases and from trauma, and there was no correlation between the severity of the pancreatic damage and the presence of stainable iron (Longnecker, 1965) or enhanced iron absorption (Deller, 1965). There is also evidence that the effect of pancreatic disease on iron absorption is not constant. For example, Jordan and Grossman (1957) noted normal iron absorption in three patients after total pancreatectomy, and Chaikoff, Connor, and Biskind (1938) did not mention excessive deposition of iron in the livers of depancreatized dogs surviving up to fiveand a half years. Klavins, Kinney, and Kaufman (1965) showed that iron absorption was normal or decreased six weeks after ethionine-induced pancreatic damage in rats. These findings are in contrast to reports that iron absorption was excessive during the first two weeks following ethionine administration (Kinney et al., 1955; Brozović et al., 1966). Finally, Murray and Stein (1964) were unable to demonstrate any increase in the uptake of ${ }^{59} \mathrm{Fe}$ in rats undergoing pancreatic duct ligation, despite complete atrophy of the pancreas.

Because of these conflicting reports it was decided to undertake a series of in vitro and in vivo studies in an attempt to establish more clearly the possible role of the exocrine pancreatic secretions in the control of iron absorption.

\section{MATERIALS AND METHODS}

Experiments were carried out both in animals and in human subjects. In the animal studies rats and dogs were used. The rats were of the Wistar strain and weighed between $15 \mathrm{~J}$ and $250 \mathrm{~g}$. The dogs were stray animals obtained from the local pound. They were deloused, dewormed, and kept on a stock diet for at least two weeks before use. The absorption of radioiron was also measured in a number of human subjects. These included
11 haematologically normal adult patients, 10 patients suffering from idiopathic haemochromatosis, eight with iron deficiency, eight with chronic calcific pancreatitis, and three with fibrocystic disease of the pancreas.

ISOTOPIC MEASUREMENTS All absorption studies were performed after an overnight fast, and food and water were withheld for a period of two hours following the administration of the test solutions. In the human studies the absorption of $5 \mathrm{mg}$. iron was assessed. This was administered as ferrous sulphate or ferric chloride, and was labelled with either $5 \mu \mathrm{c}{ }^{59} \mathrm{Fe}$ or $50 \mu \mathrm{c}{ }^{55} \mathrm{Fe}$. (In those studies in which a whole body counter was employed the dose of ${ }^{59} \mathrm{Fe}$ varied between 0.3 and $1.5 \mu \mathrm{c}$.) The volume of the test solution was made up to 50 or $100 \mathrm{ml}$. with distilled water. When pancreatic extract was used it was administered as Pancrex $\mathrm{V}^{1}$ or as Viokase ${ }^{2}$. A dose of 3-5 g. was given with water at 10.00 p.m. the previous evening and again just before the administration of the labelled iron. In the experiments with rats, $1.0 \mathrm{ml}$. test solution containing 10-50 $\mu \mathrm{g}$. iron as ferrous sulphate or ferrous ascorbate, labelled with $0 \cdot 1-0 \cdot 3 \mu \mathrm{c} .{ }^{59} \mathrm{Fe}$ or $2.5 \mu \mathrm{c}$. ${ }^{55} \mathrm{Fe}$, was administered via an oesophageal cannula. When dogs were used, $10 \mathrm{ml}$. of a solution of ferrous ascorbate was administered. It contained $250 \mu \mathrm{g}$. iron labelled with either $2.5 \mu \mathrm{c}$. ${ }^{59} \mathrm{Fe}$ or $25 \mu \mathrm{c}$. ${ }^{55} \mathrm{Fe}$. The solution was slowly instilled into the oropharynx through a plastic tube attached to a syringe, great care being taken to avoid spilling.

Several different methods were used for assessing absorption. Whenever possible a double isotope technique was employed. In this technique the iron was labelled with the one isotope on the first occasion and with the second on the following day. In this way it was possible to obtain a direct comparison of iron absorption under different conditions (Bothwell and Finch, 1962; Jacobs et al., 1964). This approach was used in the majority of the human studies and in all the dog experiments. It was also employed in some of the investigations carried out in rats. In half of the experiments the order of administration of the two isotopes was reversed. Duplicate blood samples, collected 10-14 days after the oral administration of the labelled iron solutions, were digested, electroplated onto copper discs, and differentially counted for the two isotopes as described previously (Bothwell and Finch, 1962). The percentages absorbed on each occasion were then calculated, on the assumption that $80 \%$ of the iron absorbed from the gut was present in the red cell mass at 10 to 14 days, and that the blood volume was $60 \mathrm{ml} / \mathrm{kg}$. body weight. Results were therefore corrected by a factor of $10 / 8$ in haematologically normal subjects. This was not, however, done in iron-deficient patients, since iron utilization is approximately $100 \%$ in such circumstances.

Iron absorption was measured using a human whole body counter in three patients with fibrocystic disease of the pancreas, in three patients with chronic calcific pancreatitis, and in one subject with untreated haemochromatosis. The counter consisted of a 9 in. $\times 4$ in.

'Pabyrn Laboratories, Greenford, England.

'Viobin Corp., Monticello, Ill., U.S.A. 
thallium-activated sodium iodide crystal, coupled to three E.M.I. photomultiplier tubes and a Nuclear Enterprises single-channel analyser unit. Whole body activity was measured at six hours to establish the $100 \%$ point and again every second day until a steady state was reached. This usually occurred between the seventh and tenth days. Absorption was estimated as the difference between the initial and final measurements, suitable corrections having been made for background and radioisotopic decay. When a second iron absorption study was performed the counting technique was identical, except that whole body background counts were made before the administration of the second dose of isotope, and corrections were allowed for retained activity following the first absorption study.

In some experiments on rats it was not possible to use the double isotope technique. In these studies care was taken to match the rats for weight and sex and to compare directly the performance of test animals with controls in alternate experiments carried out at the same time. In these experiments the animals were killed 24 hours after the intraoesophageal administration of the iron solution labelled with ${ }^{59} \mathrm{Fe}$. The whole of the small bowel was immediately removed intact between two ligatures, opened longitudinally and rinsed gently for half a minute in a beaker containing $200 \mathrm{ml}$. of normal saline. The remainder of the bowel was then excised, and absorption was assessed by determining the radioactivity present in the carcass using a whole body counter similar to that described by Warner and Oliver (1962).

CHEMICAL MEASUREMENTS Serum iron levels were measured by a modification of the method of Bothwell and Mallett (1955) and unsaturated iron-binding capacities by the technique of Charlton, Hardie, and Bothwell (1965). The effects of various pancreatic extracts on the valency of iron solutions were studied in in vitro experiments. In such experiments the valency and quantity of iron present were determined using $\alpha-\alpha^{1}$, dipyridyl as the colour reagent. The technique was as follows: $1 \mathrm{ml}$. test solution ( $p \mathrm{H} \mathrm{5 \cdot 4-5 \cdot 7)}$ was mixed with $1 \mathrm{ml}$. of a solution containing $0.1 \% \alpha-\alpha^{1}$, dipyridyl in saturated sodium acetate, adjusted to $\mathrm{pH}$ 5.0 with glacial acetic acid. One ml. fresh $0.2 \mathrm{M}$ sodium sulphite solution was added and the tube was then heated in a boiling waterbath for five minutes. It was allowed to cool and centrifuged for two minutes. The supernatant was diluted to a known volume and the colour was compared with a suitable standard in an Evelyn colorimeter at $515 \mathrm{~m} \mu$. This provided an estimate of the total iron content of the sample, all ferric iron having been reduced by the sodium sulphite. To determine the concentration of ferrous iron originally present, the identical procedure was repeated except that no sodium sulphite was added. The concentration of ferric iron was then obtained by difference.

\section{RESULTS}

EFFECT OF PANCREATIC EXTRACT UPON IRON SOLUTIONS IN VITRO Twenty $\mathrm{ml}$. of a solution of ferrous sulphate or ferric chloride (containing $50 \mu \mathrm{g}$. $\mathrm{Fe} / \mathrm{ml}$.) was added to $1 \mathrm{~g}$. of pancreatic extract (Viokase) and the mixture was then vigorously shaken for five minutes. Aliquots of the mixture were allowed to stand at room temperature for varying periods up to 12 hours before centrifugation at 2,000 r.p.m. for 10 minutes. The amount of iron still present in the supernatant was then measured. Iron in the ferric form was rapidly taken up by the water-insoluble fraction of pancreatic extract. By five minutes less than $20 \%$ could be recovered from the supernatant. In contrast, the uptake of ferrous iron was slower and less complete, so that at 10 minutes $55-65 \%$ of the iron was still present in the supernatant. By four and a half hours this amount had decreased to approximately $30 \%$, and by 12 hours to $15-20 \%$. Several experiments were carried out in an attempt to elucidate the nature of the iron in the supernatant fraction of pancreatic extract. First, it was shown that pancreatic extract did not alter the valency of iron. Iron in the ferric form was not reduced to the ferrous form and neither was ferrous iron oxidized to ferric iron. The effect of $5 \% \mathrm{~W} / \mathrm{V}$ pancreatic extract upon the dialysis of iron solutions against distilled water and isotonic sodium chloride solution was examined in further studies. Aqueous solutions of ferric chloride are not normally dialysable, whiie ferrous sulphate dialyses almost completely. The presence of pancreatic extract did not change the behaviour of ferric chloride, but considerably reduced the amount of ferrous sulphate which dialysed. After 12 hours $80 \%$ of the iron was still within the dialysis bag. Very similar results were obtained in experiments using the water-soluble fraction of pancreatic extract. These findings could not be ascribed simply to a change in $p H$, since the $p H$ of the ferrous sulphate solution was $5 \cdot 3$ and that of the mixture and water-soluble supernatant 5.6. The effect of three different pancreatic extracts was similar (Viokase, Cotazym ${ }^{1}$, and Pancrex V). Finally, a group of experiments was done to find out whether there was any specific iron-binding agent present in the water-soluble fraction of pancreatic extract.

Four millilitres of the supernatant of $0.75 \%$ W/V pancreatic extract (Viokase or Pancrex V) was added to $6 \mathrm{ml}$. of a solution of ferrous sulphate containing $60 \mu \mathrm{g}$. iron, and the mixture was then well shaken. The solution was allowed to stand at room tamperature for varying periods up to 12 hours. Approximately $400 \mathrm{mg}$. magnesium carbonate was then added to remove any free ionic iron. After mixing for 30 to $\mathbf{4 0}$ minutes on a rotating disc and

\footnotetext{
'Organon Laboratories Ltd., Morden, Surrey, England.
} 
centrifuging at 2,000 r.p.m. for five minutes, the amount of iron in the supernatant was measured. By one hour less than $1 \%$ could be recovered and even after 12 hours the figure was still less than $8 \%$. These results suggested that the ferrous iron was not firmly bound to any component of pancreatic extract. This conclusion was supported by the results of paper electrophoresis. A tracer amount of ${ }^{59} \mathrm{Fe}$ as ferrous sulphate was added to the watersoluble fraction of pancreatic extract, and an aliquot was electrophoresed in $0.075 \mathrm{M}$ acetate buffer at $p \mathbf{H} 5 \cdot 6$. All the radioactivity remained at the origin. Similar results were obtained when a

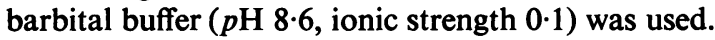

EFFECT OF PANCREATIC EXTRACT UPON IRON UPTAKE BY ISOLATED LOOPS OF RAT INTESTINE The effect of pancreatic extract on iron absorption was tested using a $20 \mathrm{~cm}$. loop of rat proximal jejunum (Davis and Biggs, 1965). The loop was isolated between two plastic cannulae under intraperitoneal pentobarbital and ether anaesthesia. In some experiments a duodeno-jejunal loop was used, beginning from a point $2 \mathrm{~cm}$. distal to the entry of the common bile duct. The loop was carefully washed through with $10 \mathrm{ml}$. saline at $37^{\circ} \mathrm{C}$. to remove residual food debris and biliary and pancreatic secretions. It was then emptied of fluid by gently blowing through 5-10 ml. of air. After clamping both tubes, $0.5 \mathrm{ml}$. of the test solution was injected into the loop through the proximal tube. Half a gram of the pancreatic extract (Viokase, Pancrex V, or Cotazym) was added to $10 \mathrm{ml}$. of a ferrous sulphate solution containing $50 \mu \mathrm{g}$. of iron per ml. After vigorous shaking the mixture was centrifuged at $2,000 \times g$ for 10 minutes. A tracer amount of ${ }^{59} \mathrm{Fe}$ was then added to the water-soluble supernatant. In other experiments $1 \mathrm{~g}$. of the extract was added to $10 \mathrm{ml}$. of distilled water and was vigorously shaken and centrifuged as before. Two millilitres of a ferrous sulphate solution containing $400 \mu \mathrm{g}$. iron was added to $6 \mathrm{ml}$. of the filtered supernate, which was then labelled with ${ }^{59} \mathrm{Fe}$. The control solution contained $50 \mu \mathrm{g}$. iron as ferrous sulphate per ml., labelled with ${ }^{59} \mathrm{Fe}$. Forty minutes later the loop was gently washed with $60 \mathrm{ml}$. saline and excised. The animal was then killed. Both the amount of labelled iron present in the washed intestinal mucosa and the proportion absorbed into the remainder of the carcass were determined.

In control experiments in 12 animals the mean absorption of iron (carcass counts) was $3 \cdot 1 \% \pm 2 \cdot 0$ S.D., and uptake of iron by the intestinal loop was $43.0 \% \pm 21.0$ S.D. When pancreatic extract was added the mean percentage of iron absorbed was $2.5 \% \pm 1.0$ S.D. and loop uptake was $38.6 \% \pm$ 23.4 S.D. Neither of these differences was significant
(P $>0 \cdot 3)$. In further studies the experimental period was shortened to 20 minutes. In seven control animals the mean absorption of iron was $2.5 \% \pm 0.7$ S.D. and uptake of iron by the loop was $40.5 \% \pm$ 18.7 S.D. After the addition of pancreatic extract the mean percentage of iron absorbed was $4.8 \% \pm$ 3.5 S.D. and loop uptake was $15 \cdot 8 \% \pm 5 \cdot 1$ S.D. Although there was a significant difference in the loop uptake $(P<0.01)$ the values for iron absorption (carcass) were not significantly different (P $>0 \cdot 1)$.

The explanation for the apparently lower uptake of iron by the loops after the addition of pancreatic extract in the 20 minute study was not apparent. The possibility that this was due to separation of the mucosal cells from the lamina propria by the action of potent proteolytic enzymes in the extract (Harrer, Stern, and Reilly, 1964) was investigated. However, the histological appearances of both the control and test loops were normal.

EFFECT OF EXCLUSION OF BILIARY AND PANCREATIC SECRETIONS ON IRON ABSORPTION IN THE RAT In 29 rats the common bile duct was tied at the porta hepatis. In a second group of 30 rats the common bile duct was ligated at its site of entry into the duodenum, effectively excluding both bile and pancreatic secretions (Richter and Benjamin, 1934). A control group of 37 rats had sham operations. In all three groups supplementary pancreatin granules were added to the food postoperatively. Food and pancreatin were withdrawn 12 hours before giving the test dose of iron. Ten micrograms of iron as ferrous ascorbate was administered two days preoperatively labelled with the one isotope and two days postoperatively labelled with the second isotope. In the sham operation control rats there was a non-specific reduction of iron absorption in the postoperative period. The mean absorptions were $18.8 \%$ preoperatively and $7 \cdot 3 \%$ postoperatively. Iron absorption was similarly depressed postoperatively in the groups of rats in which the common bile duct was tied at the porta hepatis $(19.4 \%$ and $9.4 \%)$ or at its duodenal end $(20.6 \%$ and $11 \cdot 7 \%$ ).

EFFECT OF STIMULATION OF PANCREATIC SECRETIONS BY THE INTRAVENOUS ADMINISTRATION OF SECRETIN AND PANCREOZYMIN The double isotope technique was used to study the effect of intravenous secretin and pancreozymin on iron absorption. Initially studies were carried out in rats with doses of 2 units of hormone per $\mathrm{kg}$. body weight. Secretin ${ }^{1}$ and pancreozymin (Boots ${ }^{1}$ or Vitrum ${ }^{2}$ ) were administered

${ }^{1}$ Boots Pure Drug Company Limited, Nottingham, England.

${ }^{2}$ Cecekin, Vitrum AB, Stockholm. 
to different groups of animals singly and in combination, and a fourth group was given $0.9 \% \mathrm{NaCl}$ solution. Half the dose was injected immediately before administering the isotopically labelled iron (10 $\mu \mathrm{g}$. as $\mathrm{FeCl}_{3}$ ), and the remainder 15 minutes later. On the next day the procedure was repeated, except that all the animals were injected with saline and the second isotope was used to label the iron. Absorption was assessed after 10 days by determining the amounts of each isotope present in circulating haemoglobin. Neither hormone was found to affect absorption in this dosage (Table I, experiment A). However, since the rat is relatively insensitive to both secretin and pancreozymin (Lin and Alphin, 1962) the procedure was repeated with much larger doses. Twenty units of secretin and 10 units of pancreozymin were given in divided doses and iron absorption studies were carried out in the same way as previously. Absorption was found to be diminished in animals given pancreozymin either alone or together with secretin (paired $t$ test: $P<0.01)$. There was no effect with secretin alone (Table I, experiment B). This observation was confirmed in a subsequent experiment in which the effect of pancreozymin alone was examined. The mean control absorption was $18.7 \% \pm 3.9$ S.D. compared with a figure of $7.0 \% \pm 1.8$ S.D. when pancreozymin was given $(P<0.01)$. Subsequent attempts to repeat these experiments were unsuccessful, but this was ascribed to the fact that the percentage absorptions in the whole rat colony were inexplicably low at the time. Repeat studies were eventually carried out in rats which had been maintained on an iron-free diet for two weeks. The mean absorption of $10 \mu \mathrm{g}$. iron in 12 control rats was $8 \cdot 5 \% \pm 3 \cdot 3$ S.D. as compared with $5 \cdot 7 \% \pm 3 \cdot 3$ S.D. in 12 rats given pancreozymin. The difference was probably significant $(P<0.05)$.

In three further studies the amount of iron administered was increased to $100 \mu \mathrm{g}$. but neither pancreozymin nor secretin was found to affect iron absorption at this dosage level.

In another study, secretin and pancreozymin in a dosage of 2 units per $\mathrm{kg}$. were administered to 16 dogs. The injections were given 10 minutes before and 10 minutes subsequent to the oral administration of ${ }^{59} \mathrm{Fe}$ - labelled ferrous ascorbate solution (250 $\mu \mathrm{g}$. iron). Twenty minutes later a further dose of pancreozymin was given. The procedure was repeated the following day using ${ }^{55} \mathrm{Fe}$. On this occasion $0.9 \% \mathrm{NaCl}$ solution was administered intravenously instead of the intravenous hormones. In nine dogs absorption was depressed, in five it was increased, and in two there was no change (Table II). These differences are not statistically significant $(P>0.8)$.

TABLE II

EFFECT OF SECRETIN AND PANCREOZYMIN ON IRON ABSORPTION IN DOGS

Percentage Absorption

\begin{tabular}{cc}
\hline Intravenous Saline & Intravenous Hormones \\
\hline 1.6 & 5.9 \\
63.1 & 89.4 \\
3.5 & 3.5 \\
32.5 & 25.5 \\
4.4 & 9.6 \\
24.4 & 14.0 \\
4.5 & 2.1 \\
22.8 & 14.0 \\
5.6 & 28.5 \\
22.3 & 13.8 \\
10.7 & 9.7 \\
19.3 & 7.6 \\
11.6 & 8.1 \\
12.8 & 9.2 \\
12.1 & 4.4 \\
3.5 & 23.3
\end{tabular}

EFFECT OF PANCREATIC EXTRACT UPON IRON ABSORPTION IN HUMAN SUBJECTS Haematologically normal individuals and patients with iron deficiency, idiopathic haemochromatosis, chronic calcific pancrea-

\section{TABLE I}

EFFECT OF INTRAVENOUS SECRETIN AND PANCREOZYMIN ON IRON ABSORPTION IN RATS (MEAN \pm S.D.)

\begin{tabular}{|c|c|c|c|c|c|c|c|c|}
\hline \multirow[t]{2}{*}{$\begin{array}{l}\text { Intravenous } \\
\text { Hormones }\end{array}$} & \multirow[t]{2}{*}{$\begin{array}{l}\text { No. of } \\
\text { Rats }\end{array}$} & \multicolumn{2}{|c|}{$\begin{array}{l}\text { Experiment } A^{1}: \text { Percentage Iron } \\
\text { Absorption }\end{array}$} & \multirow[t]{2}{*}{$\boldsymbol{P}$} & \multirow[t]{2}{*}{$\begin{array}{l}\text { No. of } \\
\text { Rats }\end{array}$} & \multicolumn{2}{|c|}{$\begin{array}{l}\text { Experiment B: Percentage Iron } \\
\text { Absorption }\end{array}$} & \multirow[t]{2}{*}{$\boldsymbol{P}$} \\
\hline & & $\begin{array}{l}\text { Intravenous } \\
\text { Saline }\end{array}$ & $\begin{array}{l}\text { Intravenous } \\
\text { Hormone }\end{array}$ & & & $\begin{array}{l}\text { Intravenous } \\
\text { Saline }\end{array}$ & $\begin{array}{l}\text { Intravenous } \\
\text { Hormone }\end{array}$ & \\
\hline $\begin{array}{l}\text { Secretin alone } \\
\text { Pancreozymin alone } \\
\text { Secretin and } \\
\text { pancreozymin }\end{array}$ & $\begin{array}{l}9 \\
9 \\
8\end{array}$ & $\begin{array}{l}12 \cdot 3 \pm 4 \cdot 2 \\
20 \cdot 6 \pm 4 \cdot 4 \\
13 \cdot 8 \pm 6 \cdot 2\end{array}$ & $\begin{array}{l}14 \cdot 2 \pm 5 \cdot 6 \\
17 \cdot 0 \pm 8 \cdot 0 \\
19 \cdot 0 \pm 8 \cdot 1\end{array}$ & $\begin{array}{l}>0.1 \\
>0.1 \\
>0.1\end{array}$ & $\begin{array}{l}11 \\
13 \\
12\end{array}$ & $\begin{array}{l}17 \cdot 4 \pm 10 \cdot 5 \\
31 \cdot 1 \pm 21 \cdot 8 \\
31 \cdot 0 \pm 16 \cdot 2\end{array}$ & $\begin{array}{l}17 \cdot 7 \pm 11 \cdot 5 \\
13 \cdot 8 \pm 9 \cdot 7 \\
14 \cdot 7 \pm 14 \cdot 1\end{array}$ & $\begin{array}{l}>0.1 \\
<0.01 \\
<0.01\end{array}$ \\
\hline Saline (control) & 9 & $16.9 \pm 6.9$ & $10.8 \pm 7.6$ & $0.05<>0.1$ & 12 & $27 \cdot 8 \pm 14.9$ & $27 \cdot 1 \pm 19 \cdot 7$ & $>0.1$ \\
\hline
\end{tabular}

${ }^{1}$ In experiment A 2 units of secretin and/or pancreozymin per $\mathrm{kg}$. body weight was administered intravenously In experiment B 20 units of secretin and/or 10 units of pancreozymin was administered intravenously. 
TABLE III

EFFECT OF PANCREATIC EXTRACT ON IRON ABSORPTION IN MAN

\begin{tabular}{|c|c|c|c|c|c|c|c|c|c|}
\hline \multirow[t]{2}{*}{ Group } & \multirow[t]{2}{*}{ Age } & \multirow[t]{2}{*}{ Sex } & \multirow[t]{2}{*}{ Form of Iron } & \multirow[t]{2}{*}{$\boldsymbol{H b}$} & \multirow[t]{2}{*}{ P.C.V. } & \multirow[t]{2}{*}{ Serum Iron } & \multirow{2}{*}{$\begin{array}{l}\text { Total Iron- } \\
\text { binding Capacity }\end{array}$} & \multicolumn{2}{|c|}{ Absorption (\%) } \\
\hline & & & & & & & & Control & Extract \\
\hline $\begin{array}{l}\text { Unbled } \\
\text { haemochromatotics }\end{array}$ & $\begin{array}{l}47 \\
55 \\
60 \\
50^{2}\end{array}$ & $\begin{array}{l}\mathbf{M} \\
\mathbf{M} \\
\mathbf{M} \\
\mathbf{F}\end{array}$ & $\begin{array}{l}\text { Ferrous sulphate } \\
\text { Ferrous sulphate } \\
\text { Ferrous sulphate } \\
\text { Ferrous sulphate }\end{array}$ & $\begin{array}{l}14 \cdot 1 \\
15 \cdot 1 \\
19 \cdot 4 \\
13 \cdot 8\end{array}$ & $\begin{array}{l}44 \cdot 0 \\
47 \cdot 0 \\
50 \cdot 5 \\
40 \cdot 0\end{array}$ & $\begin{array}{l}213 \\
167 \\
211 \\
197\end{array}$ & $\begin{array}{l}230 \\
192 \\
306 \\
227\end{array}$ & $\begin{array}{r}4 \cdot 3 \\
0.9 \\
10 \cdot 4 \\
11 \cdot 7 \\
-\end{array}$ & $\begin{array}{l}1 \cdot 9^{1} \\
1 \cdot 4^{1} \\
5 \cdot 0^{1} \\
51 \cdot 9^{1} \\
37 \cdot 1\end{array}$ \\
\hline $\begin{array}{l}\text { Venesected } \\
\text { haemochromatotics }\end{array}$ & $\begin{array}{l}50 \\
55 \\
50 \\
40 \\
47 \\
61 \\
52 \\
40 \\
50\end{array}$ & $\begin{array}{l}\mathbf{M} \\
\mathbf{M} \\
\mathbf{M} \\
\mathbf{M} \\
\mathbf{M} \\
\mathbf{M} \\
\mathbf{M} \\
\mathbf{M} \\
\mathbf{M}\end{array}$ & $\begin{array}{l}\text { Ferrous sulphate } \\
\text { Ferrous sulphate } \\
\text { Ferrous sulphate } \\
\text { Ferrous sulphate } \\
\text { Ferrous sulphate } \\
\text { Ferric chloride } \\
\text { Ferric chloride } \\
\text { Ferric chloride } \\
\text { Ferric chloride }\end{array}$ & $\begin{array}{l}14 \cdot 8 \\
17 \cdot 3 \\
15 \cdot 9 \\
13 \cdot 0 \\
17 \cdot 0 \\
16 \cdot 4 \\
15 \cdot 1 \\
16 \cdot 7 \\
13 \cdot 3\end{array}$ & $\begin{array}{l}49 \cdot 5 \\
51 \cdot 5 \\
49 \cdot 5 \\
45 \cdot 5 \\
55 \cdot 5 \\
47 \cdot 0 \\
41 \cdot 0 \\
44 \cdot 0 \\
39 \cdot 0\end{array}$ & $\begin{array}{r}61 \\
226 \\
214 \\
45 \\
302 \\
229 \\
49 \\
31 \\
68\end{array}$ & $\begin{array}{l}369 \\
329 \\
427 \\
287 \\
415 \\
238 \\
317 \\
268 \\
231\end{array}$ & $\begin{array}{r}83 \cdot 0 \\
17 \cdot 8 \\
60 \cdot 8 \\
62 \cdot 8 \\
50 \cdot 8 \\
6 \cdot 7 \\
51 \cdot 0 \\
3 \cdot 8 \\
39 \cdot 1\end{array}$ & $\begin{array}{c}73 \cdot 0^{1} \\
10 \cdot 9^{1} \\
51 \cdot 9^{1} \\
57 \cdot 8^{1} \\
40 \cdot 9^{1} \\
14 \cdot 1 \\
62 \cdot 8 \\
6 \cdot 1 \\
14 \cdot 2\end{array}$ \\
\hline Iron deficiency ${ }^{3}$ & $\begin{array}{l}71 \\
65 \\
36 \\
51 \\
62 \\
75 \\
69 \\
52\end{array}$ & $\begin{array}{l}\mathbf{F} \\
\mathbf{F} \\
\mathbf{F} \\
\mathbf{M} \\
\mathbf{F} \\
\mathbf{M} \\
\mathbf{M} \\
\mathbf{M}\end{array}$ & $\begin{array}{l}\text { Ferric chloride } \\
\text { Ferric chloride } \\
\text { Ferric chloride } \\
\text { Ferric chloride } \\
\text { Ferric chloride } \\
\text { Ferric chloride } \\
\text { Ferrous sulphate } \\
\text { Ferrous sulphide }\end{array}$ & \begin{tabular}{r|}
$10 \cdot 8$ \\
$11 \cdot 6$ \\
$12 \cdot 7$ \\
$13 \cdot 0$ \\
$9 \cdot 7$ \\
$9 \cdot 7$ \\
$13 \cdot 0$ \\
$11 \cdot 4$
\end{tabular} & $\begin{array}{l}39 \cdot 5 \\
40 \cdot 5 \\
43 \cdot 5 \\
- \\
- \\
35 \cdot 5 \\
40 \cdot 0 \\
32 \cdot 5\end{array}$ & $\begin{array}{l}68 \\
33 \\
66 \\
15 \\
47 \\
61 \\
28 \\
32\end{array}$ & $\begin{array}{l}456 \\
415 \\
473 \\
- \\
- \\
355 \\
339 \\
388\end{array}$ & $\begin{array}{r}38.8 \\
13 \cdot 3 \\
8.4 \\
17 \cdot 1 \\
4.5 \\
54 \cdot 2 \\
92.4 \\
6.9\end{array}$ & $\begin{array}{r}41.2 \\
12.4 \\
13.9 \\
23.8 \\
5.9 \\
30.1 \\
100.0 \\
5.9\end{array}$ \\
\hline $\begin{array}{l}\text { Chronic calcific } \\
\text { pancreatitis }\end{array}$ & & & & & & & & & \\
\hline $\begin{array}{l}\text { a) With diabetes } \\
\text { and steatorrhoea }\end{array}$ & $\begin{array}{l}50 \\
68^{2}\end{array}$ & $\begin{array}{l}\mathbf{M} \\
\mathbf{M}\end{array}$ & $\begin{array}{l}\text { Ferrous sulphate } \\
\text { Ferrous sulphate }\end{array}$ & $\begin{array}{l}14 \cdot 4 \\
15 \cdot 3\end{array}$ & $\begin{array}{l}43 \cdot 5 \\
49 \cdot 0\end{array}$ & $\begin{array}{r}69 \\
101\end{array}$ & $\begin{array}{l}327 \\
203\end{array}$ & $\begin{array}{r}8 \cdot 0 \\
13 \cdot 8\end{array}$ & $\begin{array}{l}10 \cdot 1^{1} \\
10 \cdot 9^{1}\end{array}$ \\
\hline $\begin{array}{l}\text { b) Diabetes but no } \\
\text { steatorrhoea }\end{array}$ & $\begin{array}{l}40 \\
68^{2} \\
36 \\
45^{2} \\
50\end{array}$ & $\begin{array}{l}\mathbf{F} \\
\mathbf{F} \\
\mathbf{F} \\
\mathbf{M} \\
\mathbf{M}\end{array}$ & $\begin{array}{l}\text { Ferrous sulphate } \\
\text { Ferrous sulphate } \\
\text { Ferrous sulphate } \\
\text { Ferrous sulphate } \\
\text { Ferrous sulphate }\end{array}$ & $\begin{array}{l}16 \cdot 3 \\
13 \cdot 5 \\
13 \cdot 1 \\
16 \cdot 3 \\
14 \cdot 6\end{array}$ & $\begin{array}{l}49 \cdot 5 \\
41 \cdot 0 \\
45 \cdot 0 \\
48 \cdot 0 \\
46 \cdot 0\end{array}$ & $\begin{array}{r}119 \\
162 \\
97 \\
77 \\
63\end{array}$ & $\begin{array}{l}502 \\
350 \\
377 \\
297 \\
315\end{array}$ & $\begin{array}{r}17 \cdot 4 \\
5.6 \\
13.9 \\
1.8 \\
2.8 \\
3.6\end{array}$ & $\begin{array}{l}1 \cdot 4^{4} \\
0 \cdot 5^{1} \\
7 \cdot 6 \\
1 \cdot 7 \\
2 \cdot 5^{1} \\
0 \cdot 7^{1}\end{array}$ \\
\hline $\begin{array}{l}\text { c) Not diabetic no } \\
\text { steatorrhoea }\end{array}$ & 45 & $\mathbf{M}$ & Ferrous sulphate & $18 \cdot 7$ & $56 \cdot 5$ & 160 & 287 & $5 \cdot 1$ & $1 \cdot 1^{1}$ \\
\hline Fibrocystic disease & $\begin{array}{r}17^{2} \\
6^{2} \\
8^{2}\end{array}$ & $\begin{array}{l}\mathbf{M} \\
\mathbf{M} \\
\mathbf{M}\end{array}$ & $\begin{array}{l}\text { Ferric chloride } \\
\text { Ferric chloride } \\
\text { Ferric chloride }\end{array}$ & $\begin{array}{l}16 \cdot 2 \\
15 \cdot 1 \\
-\end{array}$ & $\begin{array}{l}49 \cdot 0 \\
45 \cdot 0 \\
-\end{array}$ & $\begin{array}{l}56 \\
68 \\
-\end{array}$ & $\begin{array}{c}319 \\
455 \\
-\end{array}$ & $\begin{array}{l}57 \cdot 9 \\
18 \cdot 6 \\
13.6\end{array}$ & $\begin{array}{l}12 \cdot 3 \\
26 \cdot 3^{1} \\
26 \cdot 9^{1}\end{array}$ \\
\hline Control subjects & $\begin{array}{l}51 \\
46 \\
38 \\
80 \\
58 \\
46 \\
55 \\
37 \\
77 \\
67 \\
71\end{array}$ & $\begin{array}{l}\mathbf{M} \\
\mathbf{F} \\
\mathbf{F} \\
\mathbf{F} \\
\mathbf{F} \\
\mathbf{M} \\
\mathbf{M} \\
\mathbf{F} \\
\mathbf{M} \\
\mathbf{M} \\
\mathbf{M}\end{array}$ & $\begin{array}{l}\text { Ferric chloride } \\
\text { Ferric chloride } \\
\text { Ferric chloride } \\
\text { Ferric chloride } \\
\text { Ferric chloride } \\
\text { Ferric chloride } \\
\text { Ferric chloride } \\
\text { Ferrous sulphate } \\
\text { Ferrous sulphate } \\
\text { Ferrous sulphate } \\
\text { Ferrous sulphate }\end{array}$ & $\begin{array}{l}14 \cdot 1 \\
13 \cdot 9 \\
15 \cdot 5 \\
14 \cdot 3 \\
13 \cdot 2 \\
12 \cdot 6 \\
17 \cdot 4 \\
14 \cdot 1 \\
15 \cdot 2 \\
16 \cdot 9 \\
12 \cdot 4\end{array}$ & $\begin{array}{l}41 \cdot 0 \\
42 \cdot 5 \\
42 \cdot 0 \\
44 \cdot 0 \\
41 \cdot 5 \\
53 \cdot 5 \\
49 \cdot 0 \\
38 \cdot 5 \\
47 \cdot 0 \\
33 \cdot 0\end{array}$ & $\begin{array}{r}106 \\
101 \\
56 \\
68 \\
51 \\
91 \\
100 \\
56 \\
65 \\
85 \\
48\end{array}$ & $\begin{array}{l}- \\
- \\
350 \\
343 \\
319 \\
313 \\
356 \\
294 \\
271 \\
237 \\
202\end{array}$ & \begin{tabular}{r|}
0.8 \\
$1 \cdot 3$ \\
$0 \cdot 8$ \\
$0 \cdot 4$ \\
$1 \cdot 2$ \\
$5 \cdot 5$ \\
$4 \cdot 1$ \\
$18 \cdot 7$ \\
$6 \cdot 7$ \\
$2 \cdot 3$ \\
0.2
\end{tabular} & $\begin{array}{r}3 \cdot 3 \\
8 \cdot 4 \\
3 \cdot 1 \\
2 \cdot 1 \\
8 \cdot 0 \\
0 \cdot 7 \\
4 \cdot 7 \\
13 \cdot 7 \\
5 \cdot 5 \\
0 \cdot 5 \\
1 \cdot 7\end{array}$ \\
\hline
\end{tabular}

${ }^{1}$ Viokase. In other studies Pancrex $\mathrm{V}$ was administered.

In these studies absorption was measured by the whole-body counter technique. In all other studies the double isotope technique was used. some of these patients were receiving oral iron therapy which was stopped for the purpose of the study.

'In this study Viokase was autoclaved at a pressure of $15 \mathrm{lb}$./sq. in. for 20 minutes before administration.

titis, and fibrocystic disease of the pancreas were studied (Table III). No constant effect of pancreatic extract upon absorption was observed, with the possible exception of the group of patients with idiopathic haemochromatosis who had been subjected to multiple venesections. In six out of nine of these patients absorption was lower when the test dose of iron was administered with pancreatic 
extract. However, in several of these individuals the differences were small. It was also noteworthy that iron absorption was relatively low in six out of eight patients with chronic calcific pancreatitis $(10.1 \%$ or less). In spite of this, absorption was decreased further when the iron was given with pancreatic extract in five of these individuals. In one patient iron absorption was markedly depressed by the administration of pancreatic extract which had been previously autoclaved at a pressure of $15 \mathrm{lb}$./sq. in. for 20 minutes. In contrast, iron absorption was excessive in all three patients with fibrocystic disease. However, the administration of pancreatic extract depressed iron absorption in only one of these subjects. In the other two patients absorption was greater when the iron was administered with pancreatic extract.

\section{DISCUSSION}

There can be little doubt that some patients with pancreatic disease absorb iron excessively (Davis, 1961; Davis and Badenoch, 1962; Ball, 1964; Deller, 1965; Tönz et al., 1965). However, not all such patients absorb iron to a greater extent than normal (Deller, 1965; Jordan and Grossman, 1957). In the present investigation only two out of eight subjects with chronic calcific pancreatitis absorbed more than $10 \cdot 1 \%$ of a $5 \mathrm{mg}$. dose of ferrous sulphate. On the other hand, absorption was increased in all three individuals with fibrocystic disease. This may, however, have been due to the fact that they were children.

The reason why a proportion of patients with pancreatic insufficiency absorb iron excessively is not clear. The obvious explanation is the diminished secretion of pancreatic bicarbonate, since it has been convincingly demonstrated that the absorption of iron is enhanced at low $p \mathrm{H}$ (Jacobs et al., 1964). A second possibility lies in the reports of increased gastric acidity in experimental animals subjected to total pancreatectomy (Barcena, Bravo, Baugh, Mountain, and Dragstedt, 1956), pancreatic duct ligation (Greenlee, Johnson, Nelsen, and Dragstedt, 1961; Landor and Adams, 1962), or pancreatic fistula formation (Greenlee, Nelsen, and Dragstedt, 1959). Unfortunately there have been no studies correlating iron absorption with pancreatic and gastric secretory function or duodenal $p \mathrm{H}$ in animals. Furthermore, there is no evidence for gastric hypersecretion in patients with chronic pancreatic disease (Kravetz and Spiro, 1965; Bank, Marks, and Groll, 1966).

Several workers have presented evidence suggesting that the absence of some other constituent of the pancreatic secretions is responsible for the increased absorption of iron in patients with pancreatic disease. To a large extent this evidence is based on the finding that the administration of pancreatic extract to these patients sometimes decreases absorption (Davis and Badenoch, 1962; Saunders et al., 1963; Smith, 1964; Davis and Biggs, 1964; Strahm, 1965; Weiss, 1965; Deller, 1965). In the present investigation the results were variable. While the administration of pancreatic extract decreased iron absorption in about half the patients with chronic pancreatic disease, no effect was noted in others (Table III). In three patients absorption was even increased. This erratic response to the administration of pancreatic extract could not be correlated with the age of the patient, the type of pancreatic disease, its clinical severity, or the initial level of iron absorption. In addition, no predictable effect was obtained in normal subjects or in patients suffering from iron deficiency or idiopathic haemochromatosis. These findings are in agreement with those of other workers (Deller, 1965). Similar inconclusive results were obtained in studies carried out on rats. Although the addition of pancreatic extract to isolated intestinal loops was associated with a diminished epithelial uptake of iron in some experiments, the amount of iron crossing the mucosa was not reduced.

Since these discrepant findings failed to define the possible effects of pancreatic extract on iron absorption, further in vitro studies were carried out. It was found that the valency of iron was not affected by the extract, but that the dialysis of ferrous salts was considerably reduced. However, this seemed to be the result of loose adsorption rather than any specific binding of the iron onto some component of the extract. It is possible that the adsorption which occurred was similar to that which has been observed with certain clays which are known to interfere with iron absorption (Minnich, Okcuoglu, Tarcon, Arcasoy, Yorukoglu, Renda, and Demirag, 1966). In this context it is noteworthy that absorption was markedly depressed in one patient with chronic pancreatitis when the iron was administered together with large amounts of autoclaved pancreatic extract (Table III).

Finally a group of studies was done to find out whether iron absorption could be modified by acute alterations in pancreatic function. In one experiment using rats the pancreatic secretions were excluded from the duodenum and iron absorption was measured in the immediate postoperative period. Although a depression in absorption was noted, this appeared to be non-specific, since a similar depression was noted in sham-operated animals. Other workers, who have carried out similar experiments over longer periods, have also been unable to demonstrate 
enhanced iron absorption when pancreatic secretions are absent (Murray and Stein, 1964). In further studies pancreatic secretions were stimulated by the administration of pancreozymin and/or secretin, and iron absorption was then assessed. Although the absorption of a $10 \mu \mathrm{g}$. dose of iron was depressed in rats when pancreozymin was given, this only occurred when very large amounts of the hormone were injected. In contrast, no predictable effect on iron absorption was noted when conventional doses of pancreozymin were given to dogs. It is therefore possible that the results in rats were not the direct consequence of pancreatic stimulation, but were related to some other metabolic effect produced by the large doses of hormone which were administered.

From these various results it is difficult to reach any definite conclusions as to the possible role that the pancreas plays in iron absorption. While there is good evidence that a proportion of patients with chronic pancreatitis absorb iron excessively, it has not been established that this is a direct effect of the pancreatic insufficiency. The fact that pancreatic extract can depress this enhanced absorption in some subjects is certainly of interest, but does not provide conclusive proof. If pancreatic secretions do, in fact, modify iron absorption, it is still difficult to understand their role in the physiological control of absorption. If the results in the present study are considered, it is apparent that pancreatic extract does not reduce iron absorption in normal subjects. This can presumably be ascribed to the presence of the subjects' own pancreatic secretions within the lumen of the gut. However, it is noteworthy that pancreatic extract also did not restore to normal levels the increased absorption occurring in patients with iron deficiency and in subjects with idiopathic haemochromatosis who had been previously venesected. This suggests that the enhanced absorbing capacity shown by such individuals was not due to any lack of an inhibitor produced by the pancreas. It therefore appears probable that the pancreas plays little or no role in the physiological regulation of iron absorption. Other workers have reached a similar conclusion (Murray and Stein, 1966). They have suggested that the excessive absorption noted in some patients with pancreatic disease may be a consequence of associated liver disease, since there is evidence that iron absorption is enhanced in subjects with cirrhosis (Callender and Malpas, 1963).

\section{SUMMARY}

Although iron absorption was found to be excessive in some patients with chronic pancreatic disease, it was normal in others. The administration of pancreatic extracts had an unpredictable effect upon iron absorption in these patients, and did not restore to normal the increased absorption which occurs in subjects with iron deficiency and in patients with idiopathic haemochromatosis after venesection therapy.

Experiments in vitro failed to demonstrate specific binding of iron by pancreatic extracts. In animal experiments the surgical exclusion of pancreatic secretions from the duodenum did not enhance iron absorption, and pancreatic stimulation with conventional doses of pancreozymin and secretin had no measurable effect on iron absorption in dogs and rats. Although absorption was inhibited in rats when very large doses of pancreozymin were administered this may have been the result of some other metabolic effect of the hormone.

While these various results do not explain why some patients with chronic pancreatic disease absorb iron excessively they suggest that the exocrine secretions of the pancreas do not play an important role in the physiological control of iron absorption.

The authors are grateful to Professor D. J. du Plessis for making animal facilities available. Thanks are also due to Dr. S. Levin who allowed patients under his care to be studied and to Dr. A. Littman who kindly supplied the Vitrum pancreozymin.

\section{REFERENCES}

Andersen, D. H. (1938). Cystic fibrosis of the pancreas and its relation to coeliac disease. A clinical and pathologic study. Amer.J. Dis. Child., 56, 344-399.

Ball, P. A. (1964). Iron absorption in pancreatic failure. $E$. Afr. med. J., 41, 239-242.

Bank, S., Marks, I. N., and Groll, A. (1966). Gastric acid secretion in pancreatic disease. Gastroenterology, 51, 649-655.

Banwell, J. G., Hutt, M. S. R., Marsden, P. D., and Blackman, V. (1964). Malabsorption syndromes amongst African people in Uganda. E. Afr. med. J., 41, 188-193.

Barcena, J., Bravo, J. L., Baugh, C. M., Mountain, C. F., and Dragstedt, L. R. (1956). Effects of total pancreatectomy on gastric secretion. Surg. Forum, 7, 380-382.

Biggs, J. C., and Davis, A. E. (1963). Relationship of diminished pancreatic secretion to haemochromatosis. Lancet, $2,814$.

,- (1966). The exocrine pancreas and iron absorption. Aust. Ann. Med., 15, 36-39.

Bothwell, T. H., and Finch, C. A. (1962). Iron Metabolism, p. 32. Little, Brown, Boston.

- , and Mallett, B. (1955). The determination of iron in plasma and serum. Biochem. J., 59, 599-602.

Brozović, B., Popović, O., Obradović, D., and Pendić, S. (1966). Iron absorption in normal and d,l-ethionine-treated rats before and after the administration of pancreatin. Gut, 7, 531-534.

Callender, S. T., and Malpas, J. S. (1963). Absorption of iron in cirrhosis of liver. Brit. med. J., 2, 1516-1518.

Chaikoff, I. L., Connor, C. L., and Biskind, G. R. (1938). Fatty infiltration and cirrhosis of the liver in depancreatized dogs maintained with insulin. Amer. J. Path., 14, 101-110.

Charlton, R. W., Hardie, N., and Bothwell, T. H. (1965). A note on the measurement of the unsaturated iron-binding capacity of serum using radio-active iron. $S$. Afr. J. med. Sci., 30, 71-75.

Craig, J. M., Haddad, H., and Shwachman, H. (1957). The pathological changes in the liver in cystic fibrosis of the pancreas. Amer. J. Dis. Child., 93, 357-369. 
Davis, A. E. (1961). Relationship of disturbed pancreatic function to haemosiderosis. Lancet, 2, 749-750.

- , and Badenoch, J. (1962). Iron absorption in pancreatic disease. Ibid., 2, 6-8.

- , and Biggs, J. C. (1964). Iron absorption in haemochromatosis and cirrhosis of the liver. Aust. Ann. Med., 13, 201-203.

(1965). The pancreas and iron absorption. Gut, 6, 140-142.

Deller, D. J. (1965). Iron-59 absorption measurements by whole body counting: studies in alcoholic cirrhosis, hemochromatosis, and pancreatitis. Amer. J. dig. Dis., 10, 249-258.

Gillman, J., Gillman, T., Mandelstam, J., and Gilbert, C. (1947) Cytosiderosis and the genesis of arteriosclerosis and other fibrous tissue reactions. Nature (Lond.), 159, 875-876.

Greenlee, H. B., Nelsen, T. S., and Dragstedt, L. R. (1959). The effect of pancreatic fistula on gastric secretion. Arch. Surg., 79, 1004-1008.

—, Johnson, A. N., Nelsen, T. S., and Dragstedt, L. R. (1961). Total pancreatic duct ligation: effect on gastric secretion. Ibid., 83, 872-877.

Harrer, D. S., Stern, B. K., and Reilly, R. W. (1964). Removal and dissociation of epithelial cells from the rodent gastrointestinal tract. Nature (Lond.), 203, 319-320.

Jacobs, P., Bothwell, T., and Charlton, R. W. (1964). Role of hydrochloric acid in iron absorption. J. appl. Physiol., 19, 187-188.

$\left.-, \frac{1}{-}, 1966\right)$. Intestinal iron transport: studies using a loop of gut with an artificial circulation. Amer. J. Physiol., 210, 694-700.

Jordan, P. H., and Grossman, M. I. (1957). Pancreaticoduodenectomy for chronic relapsing pancreatitis. Arch. Surg., 74, 871-880.

Kaufman, N., Klavins, J. V., and Kinney, T. D. (1958). Excessive iron absorption in rats fed low-protein, high-fat diets. Lab. Invest., 7, 369-376.

Kinney, T. D., Finch, C. A., Kaufman, N., Hegsted, M., and Partington, P. F. (1950). The relationship of the pancreas to the absoiption of iron (abstract). Amer. J. Path., 26, 746.

-, Kaufman, N. and Klavins, J. V. (1955). Effect of ethionineinduced pancreatic damage on iron absorption. J. exp. Med., 102, 151-156.

Klavins, J. V., Kinney, T. D., and Kaufman, N. (1965). Changes in affinity of liver for iron and loss of liver iron during prolonged ethionine administration. Amer. J. Path., 46, 969-976.

Kravetz, R. E., and Spiro, H. M. (1965). Gastric secretion in chronic pancreatitis. Ann. intern. Med., 63, 776-782.

Landor, J. H., and Adams, L. A. (1962). Pancreatic duct ligation and gastric secretion. Surg. Forum, 13, 292-294.
Lin, T. M., and Alphin, R. S. (1962). Comparative bio-assay of secretin and pancreozymin in rats and dogs. Amer. J. Physiol. 203, 926-928.

Longnecker, D. S. (1965). Hepatic iron stores in patients with cystic fibrosis. Arch. Path., 80, 148-152.

Minnich, V., Okcuoglu, A., Tarcon, Y., Arcasoy, A., Yorukoglu, O., Renda, F., and Demirag, B. (1966). The effect of clay on iron absorption: a possible cause for anaemia of Turkish subjects with pica. XIth Congress of the International Society of Haematology (abstract), p. 193. Blight Sydney.

Murray, M. J., and Stein, N. (1964). The effect of ligation of the pancreatic duct of rats on the absorption of $\mathrm{Fe}^{50}$ and its deposition in the liver. J. Lab. clin. Med., 64, 989-990.

- - (1966). Does the pancreas influence iron absorption? A critical review of information to date. Gastroenterology, $51,694-700$.

Richter, C. P., and Benjamin, J. A., (Jnr.) (1934). Ligation of the common bile duct in rat: anatomic and behaviouristic effects. Arch. Path., 18, 817-826.

Saunders, S. J., Bank, S., Airth, E., and Williams, J. (1963). Iron absorption in pancreatic disease. (Abstract). S. Afr. med. J., 37, 1106.

Smith, N. J., Rosello, S., Say, M. B., and Yeya, K. (1955). Iron storage in the first five years of life. Pediatrics, 16, 166-171.

Smith, R. S. (1964). Iron absorption in cystic fibrosis. Brit. med. J., 1, 608-609.

Stein, A. A., Porta, E., Powers, S., Jnr., Leather, R., Linton P., and Patterson, P. (1963). Studies on surgical biopsies of pancreas and liver in four cases of cystic fibrosis: morphologic and histochemical. Ann. Surg., 157, 516-524.

Strahm, H. W. (1965). Die Eisenabsorption bei Pankreasfibrose. II. Die absorption von Haemoglobineisen. Thesis, Berne. Quoted by Tönz, et al.

Taylor, J., Stiven, D., and Reid, E. W. (1931). Haemochromatosis in a depancreatised cat. J. Path. Bact., 34, 793-797.

$-,-1,1935)$. Experimental and idiopathic siderosis in cats. Ibid., 41, 397-405.

Tönz, O., Weiss, S., Strahm, H. W., and Rossi, E. (1965). Iron absorption in cystic fibrosis. Lancet, 2, 1096-1099.

Warner, G. T., and Oliver, R. (1962). A plastic phosphor well counter for sample volumes up to $400 \mathrm{ml}$. Brit. J. Radiol., 35, 349-352.

Weiss, S. (1965). Die Eisenabsorption bei Pankreasfibrose. I. Die Absorption von Eisensalzen. Thesis, Berne. Quoted by Tönz, et al. 